J. Reprod. Fert. (1967) 13, 501-504

\title{
AN EFFECT OF COLD EXPOSURE AT BIRTH ON THE REPRODUCTION OF MICE
}

\author{
S. A. BARNETT AND KIRSTEEN A. BORLAND \\ Zoology Department, Glasgow University
}

(Received 26th September 1966)

\begin{abstract}
Summary. Mice of strain A2G/Tb, of a stock adapted to an environment kept at $-3^{\circ} \mathrm{C}$, were fostered shortly after birth on to $A 2 \mathrm{G} / \mathrm{Tb}$ mice breeding at $21^{\circ} \mathrm{C}$. The parents of one group (a), were transferred to $21^{\circ} \mathrm{C}$ before the birth of a litter; those of a second group (b), were left in the cold. The group (b) young, which were exposed to cold for a few hours after birth, were heavier at 10 and 21 days than those of group (a). Mice of both groups were mated: those of group (b) had a lower death rate among their nestlings than those of group (a). Offspring of group (b) were also mated; the mortality among their nestlings resembled that of group (a) nestlings.
\end{abstract}

\section{INTRODUCTION}

If female mammals are exposed to adverse conditions during pregnancy and lactation, the development of their young may be affected by (i) changes in the uterine environment, and (ii) alteration in conditions in the nest, including the milk supply. One method of distinguishing these effects is cross-fostering: young are transferred soon after birth to a mother treated in a different way from the true mother. This method is being used to analyse the effects of a cold environment on the reproduction of mice (Barnett, 1965). Some observations made in this way have suggested that exposure of young to cold for a few hours immediately after birth can influence their development, and especially their reproductive performance. This hypothesis has been tested in the experiments described below.

\section{METHOD}

All the mice used were of the highly inbred strain A2G/Tb. Two breeding colonies of this strain are kept permanently, one in a room at $21^{\circ} \mathrm{C}$, one at $-3^{\circ} \mathrm{C}$. Both rooms have a 12-hr light-dark cycle. The mice used for experiment were members of the 23rd to 28th generations of the colony in the cold environment. All breeding animals were in permanently mated pairs to the age of 28 weeks. They were inspected daily for litters, at about 10.00 hours. If a pair had a litter at 28 weeks, it was kept until that litter reached weaning age, namely, 3 weeks. All mice had cotton wool bedding; at $-3^{\circ} \mathrm{C}$ water was supplied as blocks of ice which were licked. 
Two groups of mice were studied. The first were the offspring of parents which were removed from the cold environment shortly before the birth of a litter. The transfer was made when the female was at a late stage of her third pregnancy. The mean interval between transfer and birth of the litter was 3.6 days. If the expected litter had not been born within 7 days of the transfer to the warm environment, it was not used. Nor was it used if fewer than four were born. A newly born litter was reduced to four young, and fostered onto a pair of the mice living and breeding at $21^{\circ} \mathrm{C}$. Each pair of foster-parents had already reared at least one litter, and had had another litter within the $72 \mathrm{hr}$ before the fostering. This litter was removed immediately before the transfer of the fostered young. The procedure ensured that the foster-mothers were fully capable of rearing new-born young (unpublished). If one further litter of four or more was born to a transferred pair, it was fostered in the same way. The second group differed from the first only in that the parents remained in the cold environment.

Hence the mice of both groups were reared, in litters of four, by foster parents belonging to a colony of 'normal' mice at $21^{\circ} \mathrm{C}$. All had a long ancestry at $-3^{\circ} \mathrm{C}$, but the first group were born in the warm environment, the second in the cold. The exact time of birth of the litters, and hence the exact age in hours at which fostering took place, was not known. Fostering was, however, carried out only when the young had been gathered together by their mother, and had lost the bright pink appearance of mice immediately after birth.

The weights of the fostered litters were recorded at the time of fostering (Day 0) and on Days 10 and 21. They were weaned at 21 days. At 35 days all possible brother-sister pairs were mated, still at $21^{\circ} \mathrm{C}$, and their reproductive performance was recorded till they reached 28 weeks. In addition, some of the offspring of those born in the cold environment were mated, and their breeding similarly recorded.

\section{RESULTS}

Table 1 gives the mortality in the fostered litters, and the litter weights. There was no significant difference between the first and second litters born in the warm environment; hence the figures of these litters were pooled. Since the number of its litter mates influences a nestling's growth rate, the mean weights of litters of which no members were lost are given, as well as the means for all litters.

Mortality was lower among the mice born in the cold, but not significantly so. The litters born in the cold were heavier, at both 10 and 21 days, than those born in the warm environment. At 21 days complete litters born in the cold were almost exactly $10 \%$ heavier than those born in the warm. However, the percentage increases from birth to 21 days did not differ significantly; hence the figures for growth are equivocal.

The reproductive performance of the fostered mice is summarized in Table 2, columns (a) and (b). The only significant difference was in nestling mortality, which was decisively lower for the mice born in the cold. When the young of these mice were in turn mated (column c), the mortality among their nestlings was the same as that among those of the other mice born in the warm. 
TABLE 1

GROWTH OF FOSTERED LITTERS (EACH MEAN IS FOLLOWED BY ITS STANDARD ERROR)

\begin{tabular}{|c|c|c|c|c|c|c|}
\hline & \multirow{2}{*}{$\begin{array}{l}\text { No. of } \\
\text { litters }\end{array}$} & \multicolumn{2}{|c|}{$\begin{array}{l}\text { Mortality }(\%) \text { between } \\
\quad \text { birth and weaning }\end{array}$} & \multicolumn{3}{|c|}{ Mean litter weights $(\mathrm{g})$} \\
\hline & & $\begin{array}{l}\text { Whole } \\
\text { litters }\end{array}$ & $\begin{array}{c}\text { Individual } \\
\text { young }\end{array}$ & Day 1 & Day 10 & Day 21 \\
\hline $\begin{array}{l}\text { All litters: } \\
\text { Born in warm } \\
\text { Born in cold }\end{array}$ & $\begin{array}{l}67 \\
26\end{array}$ & $\begin{array}{l}21 \cdot 3 \\
15 \cdot 4\end{array}$ & $\begin{array}{l}31 \cdot 3 \\
26 \cdot 6\end{array}$ & $\begin{array}{l}6 \cdot 2 \pm 0 \cdot 07 \\
6 \cdot 6 \pm 0 \cdot 31\end{array}$ & $\begin{array}{l}24 \cdot 0 \pm 0 \cdot 87 \\
27 \cdot 6 \pm 1 \cdot 11 *\end{array}$ & $\begin{array}{l}34.9 \pm 1 \cdot 66 \\
40.5 \pm 0.65 *\end{array}$ \\
\hline $\begin{array}{l}\text { Totally surviving } \\
\text { litters: } \\
\text { Born in warm } \\
\text { Born in cold }\end{array}$ & $\begin{array}{l}32 \\
14\end{array}$ & - & $\overline{-}$ & $\begin{array}{l}6 \cdot 3 \pm 0 \cdot 10 \\
7 \cdot 0 \pm 0 \cdot 47 *\end{array}$ & $\begin{array}{l}26 \cdot 4 \pm 0 \cdot 74 \\
29 \cdot 2 \pm 0.86^{*}\end{array}$ & $\begin{array}{l}41 \cdot 8 \pm 1 \cdot 10 \\
46 \cdot 4 \pm 1 \cdot 25^{* *}\end{array}$ \\
\hline
\end{tabular}

The numbers of mated pairs are given in Table 2.

TABLE 2

EFFECT OF AMBIENT TEMPERATURE, DURING FIRST HOURS AFTER BIRTH, ON REPRODUCTIVE PERFORMANCE OF MICE: MEANS WITH STANDARD ERRORS

\begin{tabular}{l|c|c|c}
\hline & $\begin{array}{c}(a) \\
\text { Born in warm } \\
\text { environment }\end{array}$ & $\begin{array}{c}(b) \\
\text { Born in cold } \\
\text { environment }\end{array}$ & $\begin{array}{c}(c) \\
\text { Offspring of } \\
(b)\end{array}$ \\
\hline No. of mated pairs & 38 & 12 & 12 \\
Litters born/pair & $5 \cdot 2 \pm 0 \cdot 17$ & $5 \cdot 2 \pm 0 \cdot 24$ & $5 \cdot 2 \pm 0 \cdot 24$ \\
Young born/pair & $36 \cdot 1 \pm 1 \cdot 54$ & $32 \cdot 1 \pm 2 \cdot 28$ & $34 \cdot 0 \pm 1 \cdot 40$ \\
Young weaned/pair & $27 \cdot 0 \pm 1 \cdot 45$ & $27 \cdot 8 \pm 2 \cdot 39$ & $26 \cdot 6 \pm 1 \cdot 40$ \\
Per cent loss/pair & $25 \cdot 3 \pm 2 \cdot 10$ & $13 \cdot 4 \pm 3 \cdot 53^{*}$ & $25 \cdot 2 \pm 4 \cdot 24$ \\
\hline
\end{tabular}

* Significantly different from (a) $(P<0.01)$.

\section{DISCUSSION}

The temperature of the nests in the cold environment fluctuates, and is usually below that of nests in the warm: even a well-made nest with a young litter falls quickly from over $30^{\circ} \mathrm{C}$ to about $24^{\circ} \mathrm{C}$ when the parents are temporarily absent (Barnett, 1956). The observations described above suggest that exposure of mice to cold for a few hours after birth has a favourable effect both on growth and on parental efficiency. The experiments, however, could not be fully controlled. (i) The females transferred to the warm environment before the birth of their young were, during the last days of pregnancy, inevitably in an environment which differed from that of the parents of the other group. However, the absence of a difference between the first and second litters born in the warm at least suggests that the abrupt transfer from a sub-arctic to a sub-tropical temperature had no short-term ill effects. This is confirmed by the similarity of the reproductive performance of groups (a) and (c), shown in Table 2. (ii) The newborn mice of the two groups were exposed, during their first hours, not only to different nest temperatures, but also to parents which 
were themselves in different conditions. This could have influenced parental behaviour; and the different behaviour, rather than the ambient temperature, could have affected the young (cf. Barnett \& Burn, 1967).

Nevertheless, it seems more likely that the temperature of the nest during the first hours after birth was the crucial factor. Trojanová \& Mourek (1966) have published figures which suggest that exposure of 5-day laboratory rats to hypothermia can increase growth rate. Barnett \& Burn (1967) exposed mice aged 6 to 11 days daily to moderate cold for $90 \mathrm{~min}$; these mice were superior in several aspects of reproductive performance to unexposed controls. Much other work (reviewed by Levine, 1962) has been done on the effects of exposure, in early life, to various sorts of disturbance or adverse conditions. The observations described above suggest that environmental temperature during the first hours after birth can have a lasting effect on development.

\section{ACKNOWLEDGMENTS}

The research was aided by generous grants from the Science Research Council, the Medical Research Council, the Wellcome Trust and the Royal Society.

\section{REFERENCES}

BARNETt, S. A. (1956) Endothermy and ectothermy in mice at $-3^{\circ}$ C. F. exp. Biol. 33, 124.

Barnett, S. A. (1965) Adaptation of mice to cold. Biol. Rev. 40, 5.

BARNetT, S. A. \& Burn, J. (1967) Early stimulation and maternal behaviour. Nature, Lond. 213, 150.

Levine, S. (1962) The effects of infantile experience on adult behavior. Experimental Foundations of Clinical Psychology. Ed. A. J. Bachrach. Basic Books, New York.

Trojanoví, M. \& Mourek, J. (1966) The effect of thyroidectomy at early ontogenetic stages upon oxidative processes in the rat brain. Physiologia bohemoslov. 15, 231. 